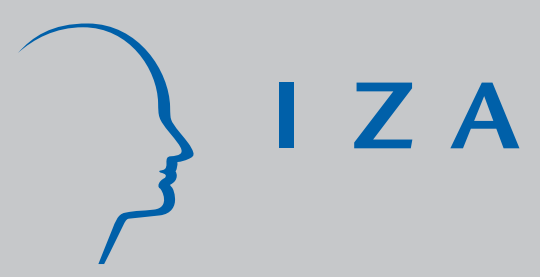

IZA DP No. 3677

Training, J ob Satisfaction and Workplace Performance in Britain: Evidence from WERS 2004

Melanie K. J ones

Richard J. J ones

Paul L. Latreille

Peter J. Sloane

September 2008 


\title{
Training, Job Satisfaction and Workplace Performance in Britain: Evidence from WERS 2004
}

\author{
Melanie K. Jones \\ WELMERC, Swansea University \\ Richard J. Jones \\ Office for National Statistics, Newport \\ Paul L. Latreille \\ WELMERC, Swansea University \\ Peter J. Sloane \\ WELMERC, Swansea University \\ and IZA
Discussion Paper No. 3677
September 2008 \\ IZA \\ P.O. Box 7240 \\ 53072 Bonn \\ Germany \\ Phone: +49-228-3894-0 \\ Fax: +49-228-3894-180 \\ E-mail: iza@iza.org
}

\begin{abstract}
Any opinions expressed here are those of the author(s) and not those of IZA. Research published in this series may include views on policy, but the institute itself takes no institutional policy positions.

The Institute for the Study of Labor (IZA) in Bonn is a local and virtual international research center and a place of communication between science, politics and business. IZA is an independent nonprofit organization supported by Deutsche Post World Net. The center is associated with the University of Bonn and offers a stimulating research environment through its international network, workshops and conferences, data service, project support, research visits and doctoral program. IZA engages in (i) original and internationally competitive research in all fields of labor economics, (ii) development of policy concepts, and (iii) dissemination of research results and concepts to the interested public.
\end{abstract}

IZA Discussion Papers often represent preliminary work and are circulated to encourage discussion. Citation of such a paper should account for its provisional character. A revised version may be available directly from the author. 
IZA Discussion Paper No. 3677

September 2008

\begin{abstract}
Training, Job Satisfaction and Workplace Performance in Britain: Evidence from WERS 2004

This paper analyses the relationship between training, job satisfaction and workplace performance using the British 2004 Workplace Employee Relations Survey (WERS). Several measures of performance are analysed including absence, quits, financial performance, labour productivity and product quality. While there is clear evidence that training is positively associated with job satisfaction, and job satisfaction in turn is positively associated with most measures of performance, the relationship between training and performance is complex, depending on both the particular measures of training and of performance used in the analysis.
\end{abstract}

JEL Classification: J0, J2, J3

Keywords: training, job satisfaction, absence, quits, financial performance, labour market, product quality

Corresponding author:

Peter J. Sloane

WELMERC, Economics Department

University of Swansea

Singleton Park

Swansea, SA2 8PP

United Kingdom

E-mail: p.j.sloane@swansea.ac.uk 


\section{Introduction}

In recent years job satisfaction has received a great deal of attention from economists and policymakers. Traditionally, economists had distrusted the use of subjective and attitudinal variables, but early papers established that job satisfaction was related to a number of objective job features and was able to predict consequences such as absenteeism and quits (Hamermesh, 1977; Freeman, 1978; and Borjas, 1979). In this paper we extend this analysis by addressing three main questions. First, does training affect job satisfaction? Second, does training affect workplace performance either directly or indirectly through its effect on job satisfaction? Third, does job satisfaction affect performance, whether or not it is related to training? Training is one means of improving manpower utilisation and thereby potentially raising job satisfaction. Either or both of these may impact favourably on establishment performance, and the purpose of this paper is to identify these mechanisms and their impact on various measures of performance.

There are a number of difficulties in establishing linkages between training and workplace performance $^{1}$, not least in measuring the latter, there being no single definition. Various measures include productivity, product quality, financial performance, pay rates, turnover, efficiency scrap rates, labour turnover, job creation, absenteeism, perceived organisational performance and perceived market performance. Second, there is unlikely to be a single generic cause of productivity or profitability; there are a number of ways in which firms can become successful, including re-skilling and work intensification. A further difficulty arises from the way data are collected. Many studies rely heavily on single respondents within an organisation, who may not be able to assess adequately relative performance. The crosssectional nature of many studies also means that the causal links between the variables chosen cannot always be firmly established.

\footnotetext{
${ }^{1}$ For a full discussion see Grugulis and Stoyanova (2006).
} 


\section{Literature Review}

a) The Effect of Training on Job Satisfaction

Most of the literature in this area has focused on the impact of education and skills on job satisfaction rather than the effect of training as such. One exception is Siebern-Thomas (2005) who, analysing 13 countries in the European Community Household Panel (ECHP) 1994-2001, found that job satisfaction tended to be higher where there was access to workplace training.

The relationship between skill acquisition and job satisfaction is not straightforward. First, there is the distinction between general and specific skills. The portability of general skills may raise job satisfaction as it is easier to move to other jobs where satisfaction is higher. In contrast, specific skills bind the worker to the firm and may reduce satisfaction by creating a barrier to exit as workers will lose a portion of the return on such skills if they move. This leads on to the question of the matching of individual skills and levels of education with job requirements. If workers are mismatched in terms of skill and education requirements, this may lower job satisfaction, as evidenced in the earlier literature.

In fact, most studies have focused on over- and under-education rather than over-skilling and under-skilling. Thus, Hersch (1991) found for the US that over-educated workers were less satisfied than adequately educated workers and (1995) that over-educated workers received less on-the-job training, but were more likely to be promoted. Yet Battu et al. (2000) found a negative relationship between over-education and promotion for UK graduates and no evidence of employers upgrading tasks given to the over-educated. The same authors (1999) found that over-educated graduates had significantly lower job satisfaction than those who were in graduate-level jobs. Green and Tsitsianis (2005) likewise found for a cross-section of 
workers that job satisfaction was lower for both over-educated and under-educated workers in their British sample, while for Belgium, Verhaest and Omey (2004) reported that after controlling for educational attainment, over-educated workers were less satisfied, more mobile, participated less in training and earned less than adequately educated workers. In contrast, Buchel (2002) found no significant difference in job satisfaction between overeducated and adequately educated employees in his study of German firms.

In one of the few studies to focus on skilling, Allen and van der Velden (2001) differentiated between education and skill mismatches, finding only a weak relationship between the two. Importantly, they found a significant negative relationship between skill mismatch and job satisfaction, while the link between education mismatch and job satisfaction was insignificant. Bauer (2004), using the European Survey on Working Conditions covering all EU member states, found that involvement of workers in High Performance Work Organisations (HPWOs) ${ }^{2}$ was associated with higher job satisfaction. Further, a skill index, derived from information on the number of days of training paid for or provided by the employer had, with the UK being an exception, a positive and significant effect on the 15 countries overall. ${ }^{3}$

\section{b) Training and Workplace Performance}

Training may influence workplace performance directly by raising output per worker, or be measured indirectly through its impact on the wage on the assumption that this is equal to the marginal productivity of labour. However, this will not be the case if there are imperfections in the product or labour markets. Dearden et al. $(2000,2006)$ were able to measure the impact

\footnotetext{
${ }^{2}$ HPWOs are organisations which take a strategic approach towards managing people, recognising that the full benefits of workforce development can only be achieved by adopting a wide array of workplace changes and human resource practices which impact on performance. See, for instance, Becker and Huselid (1998).

${ }^{3}$ WERS 2004 included a question on over-skilling, with over half the sample of employees falling into this category.
} 
on productivity directly using a panel of British industries over the period 1983 to 1996 . They found that a one percentage point increase in training was associated with an increase in value added per hour of about 0.6 per cent, but an increase in wages of only 0.3 per cent, consistent with employer monopoly power in the labour market, so that using wages as a proxy for productivity would tend to under-estimate actual productivity. Over-education or over-skilling could also moderate any influence on performance. Thus, Tsang and Levin (1985) argued that over-education could lead to reduced work effort, increased production costs and thus lower productivity. Using a firm-based production model they confirmed this hypothesis (see also Tsang, 1987) and also found a negative relationship with firm profits. Tsang et al. (1991) also found that over-educated workers, and particularly those with higher levels of education, had lower job satisfaction.

The nature of training has been examined in a number of studies. Thus Barrett and O’Connell (1998) found that specific training had a bigger impact on wages and productivity than general training. Mason et al. (1996) found that both value added and product quality were higher where workers were trained to take charge of several production lines at once. Cosh et al. in a series of papers (1998, 2000 and 2003) found that training had a strong and significant effect on employment growth in small firms when it was undertaken regularly rather than on an ad hoc basis. Especially for larger firms there was also an association between intensity of training and profitability. Training may also stimulate innovation in the workplace (Bartel and Lichtenberg, 1987). Therefore it is doubtful whether different types of training impact either equally or positively on performance.

Finally, training can have an indirect effect on performance if it increases job satisfaction by, for example, making it easier for employees to perform the job or feel more valued (as in 
Akerlof's 1982 conceptualisation of the labour contract as a gift-exchange). Petty et al.'s 1984 meta-analysis confirms such outcomes. In contrast, if workers feel dissatisfied they may react in a number of ways (Farrell, 1983): through a sense of loyalty they may stick it out; use a voice mechanism (Freeman, 1978, Freeman and Medoff, 1984); neglect their responsibilities to the employer by absence, lateness, striking or reduced effort (Akerlof and Yellin, 1986); or exit (Jovanovic, 1979, Burdett and Mortenson, 1998).

\section{c) Job Satisfaction and Quits}

Until recently there had been relatively few studies by economists examining the role played by job satisfaction in quitting decisions. The main reason for this was the lack of largesample longitudinal data which could be used to identify job satisfaction in one period and job turnover in subsequent periods. Locke (1976) provided an extensive review of the literature in the psychology field, concluding that a negative correlation coefficient between job satisfaction and employee turnover was almost always obtained. However, correlation does not always imply causation and most of the studies cited by Locke used simple univariate analysis. In one of the seminal papers on job satisfaction, Freeman (1978) was one of the first economists to analyse the connection between quits and job satisfaction. Based on panel data from two different US sources, the National Longitudinal Survey (NLS, 19661971) and the Michigan Panel Survey of Income Dynamics (PSID, 1972-73), Freeman showed that job satisfaction was positively and significantly related to the probability of quitting. Moreover, he found not only that job satisfaction was quantitatively more important than wages, but also that the causality ran from job satisfaction to future quitting behaviour.

This relationship was confirmed by Akerlof et al. (1988) using data from the NLS Older Men Survey. More recently, Clark et al. (1998) using data from ten waves of the German Socio- 
Economic Panel (1984-93) found that workers who reported dissatisfaction with their jobs were statistically more likely to quit than those with higher levels of satisfaction.

Using data from the Danish section of the ECHP, Kristensen and Westergård-Nielsen (2004) found that the inclusion of a subjective measure of job satisfaction improved the predictive ability of a job quit model. Dissatisfaction with the type of work was found to be the aspect most likely to lead to a worker leaving their job, whilst satisfaction with job security was found to have an insignificant effect on quit propensity. The authors contrast this finding with results from the UK, where dissatisfaction with job security is usually found to be one of the most important predictors of quit behaviour. They attribute this discrepancy to the differing generosities of the benefit systems in the two countries.

Concerns about recruitment and retention difficulties in the public health and education sectors in the UK prompted studies by Shields and Ward (2001) and Frijters et al. (2004). Shields and Ward (2001) investigated the determinants of job satisfaction for nurses in the UK and established the importance of job satisfaction in determining nurses' intentions to quit the National Health Service (NHS). They found that nurses who reported overall dissatisfaction with their jobs had a $65 \%$ higher probability of intending to quit than those reporting to be satisfied. Frijters, et al. (2004) examined the factors influence the quitting decision of public sector teachers in England and Wales using a panel data of 29,801 observations on 7,989 different teachers drawn from the quarterly Labour Force Survey between 1997 and 2003. They argued that improving job satisfaction through non-pecuniary aspects of teachers' jobs has a larger impact on improving retention than increasing pay. Brown and McIntosh (1998) applied principal components analysis to data from a survey of employees from three low-wage service sector companies. They found that satisfaction with 
short-term rewards and long-term prospects were far more influential in determining overall satisfaction than contentment with social relationships or work intensity.

The aforementioned relative shortage of longitudinal data means that researchers have tended to focus on the relationship between job satisfaction and their future employment expectations or intentions (i.e. 'latent' turnover). The use of intentions to quit rather than observed quit raises the question how good a predictor of actual quitting is reports to quit?

\section{d) Job Satisfaction and Absenteeism}

Absenteeism is the term generally used to refer to unscheduled employee absences from the workplace. Absenteeism can impose a number of costs on employer such as the lost output of the absent employee; overtime for other employees to fill in; any temporary help costs incurred; possible loss of business or dissatisfied customers etc (Oi, 1962). In contrast some psychologists have found that absenteeism may be beneficial as it provides some temporary relief from the stresses of work (Steers and Rhodes, 1978). Many authors (e.g. Barmby et al., 1994) have tried to distinguish between voluntary and involuntary absence but this has proven to be difficult. Barmby et al. (1991) report that the majority of sickness absence is in the UK is in spells of five days or less; a finding supported by Labour Market Trends (2003) which showed that of those workers who were absent during a reference week, $40 \%$ of workers claimed absence for a period of only one day and approximately $75 \%$ claimed absence for 4 days or less. Both these suggest strongly that much absenteeism is on the basis of self certification of illness and this has been cited as support for the voluntary absence hypothesis. 
Economists have investigated the issue from both a supply and demand side perspective. On the supply side, Paringer (1983) and Bridges and Mumford (2001) have found that older and single workers were more likely to be absent, especially for men. On the demand-side, Barmby and Stephan, (2000) found that larger firms tend to have higher rates of absenteeism which arises because of their ability to diversify the risk from absence more easily. Workers who are employed on full-time contracts are more likely to be absent than part-time workers (Barmby et al., 1995 and Barmby 2002), whilst Ichino and Riphahn (2005) show that the ending of any probationary period and employment protection legislation both tend to increase absenteeism.

A number of authors have considered the relationship between job satisfaction and absence. In an early study conducted by Vroom (1964), low levels of job satisfaction were found to contribute to higher absenteeism rates. A finding confirmed by Clegg (1983) who also found that low job satisfaction was also associated with a lack of punctuality and a higher propensity to quit. Drago and Wooden (1992) conducted a comparative study examining the causes of absenteeism using data from a survey of 601 workers from Australia, New Zealand, Canada, and the United States. Their results indicated that absenteeism was lower in occupations where employees worked together closely and harmoniously and where job satisfaction was high. Finally, Wegge et al. (2004) utilised a sample of 436 employees working in a large civil service department and found that the hypothesized interaction between satisfaction and involvement was significant for both their indicators of absence behaviour

Absenteeism caused by low job satisfaction is consistent with both the involuntary and voluntary absence schools. As noted above, low job satisfaction can stimulate withdrawal 
(voluntary absence). However, low job satisfaction has also been linked to a range of health issues especially mental/psychological problems (Faragher et al., 2005) and absence in this way can be thought of as involuntary.

As noted by Zwick (2006), a major estimation problem, particularly when the data set used as in our case is cross-sectional arises from the endogeneity of training and other production inputs such as labour and capital. As firms do not randomly select workers for training, but rather those most likely to benefit from it, training is not wholly exogenous. There are in fact two distinct biases: unobserved time invariant heterogeneity and endogeneity bias in relation to training intensity. In the case of the former, some firms may be inherently more or less productive than others. In fact, Bartel (1994) for the US, Dearden et al. $(2000,2006)$ for the UK and Zwick (2006) for Germany all find that less productive firms are more likely to implement formal training programmes than high productivity firms, which means that the effect of training on establishment performance is likely to be understated. Endogeneity bias may be caused by transitory shocks such as the introduction of new technology and changes in labour and product market conditions. Firms may well choose to train when demand is low (the 'pit-stop' theory). Further, the effects of training may be spread over a number of years and although our training questions cover the previous twelve months, this may not be enough to capture the full effects. For all these reasons our estimates of the effects of training on performance are likely to be lower bound estimates. Our job satisfaction measures are however less likely to suffer from problems of endogeneity as training is much more likely to influence levels of job satisfaction than the reverse. Further, levels of job satisfaction seem more likely to influence levels of performance than the reverse, particularly since performance is measured relative to competitors. We also have a large number of controls to pick up factors such as labour quality, tenure and establishment characteristics. 


\section{Data}

The data set used in our analysis is the Workplace Employment Relations Survey (WERS) 2004, a national survey of British workplaces with 5 or more employees. The survey covers establishments from all industry sectors except for establishments engaged in primary industries and private households with domestic staff (7 per cent of all workplaces). The survey is the fifth, and most recent, survey in the Workplace Industrial Relations Survey (WIRS) Series; previous studies having taken place in 1980, 1984, 1990 and 1998.

From each workplace an interview is conducted with the senior person at the workplace with day-to-day responsibility for industrial relations, employee relations or personnel matters and with the most senior representative of the trade union with the largest number of members at the workplace, or with the most senior employee representative who sits on a workplace-level consultative committee. Moreover, a randomly selected sample of 25 individuals from these workplaces was questioned on a range of topics ${ }^{4}$. One of the main advantages of this survey is that it allows the linking of responses from particular workplaces thus enabling us to examine worker and workplace characteristics. There are around 2,300 workplaces in the dataset and 22,500 associated employees.

We consider six direct measures of job satisfaction. Specifically, workers were asked how satisfied they were with:

1. the sense of achievement they get from work (achievement);

2. the scope for using own initiative (initiative);

3. the influence over the job (influence);

4. the training they receive (training);

\footnotetext{
${ }^{4}$ Or every employee in workplaces with between 5 and 24 employees.
} 
5. the amount of pay they receive (pay);

6. the work itself (work itself).

Workers are asked to rate their satisfaction on a five point scale with 1 representing 'very dissatisfied’; 3 ‘neither satisfied nor dissatisfied' and 5 being ‘very satisfied’.

The measure of training used for the individual level analysis is based on the response given to the question, 'Apart from health and safety training, how much training have you had during the last 12 months, either paid for or organised by your employer?' Respondents are instructed only to include training where they had been given time off from their normal daily work duties to undertake the training. The distribution of responses to this question is shown in Table 1. This shows that almost two-thirds of workers asked had received some training in the previous year. Of those who had received training, the most common duration was between 2 and 5 days.

We measure training in the workplace-level analysis in three different ways using both employee and management questionnaires. The first two measures are based on responses from the management questionnaire. The first question is: 'What proportion of experienced members of the largest occupational group (LOG) have been given time off from their normal daily work duties to undertake training over the past 12 months?' The second is: 'On average, how many days of training did experienced members of the largest occupational group undertake over the past 12 months?' The third training measure is derived from the employee questionnaire, by calculating the proportion of the workers interviewed at each workplace who said that they have received training in the previous year. The distribution of responses to these questions and the average value of each of the different performance indicators (see below) are shown in Table 2. Also shown are Pearson correlation measures and associated t- 
test P-values between the training variables and performance indicators. One limitation of the former in the WERS 2004 data is that there is no direct information on the provision of informal (on-the-job) training, which tends to be the most common form of training.

An issue which arises with regard to the above concerns the extent to which the largest occupational group is representative of the wider workplace. In the absence of data on training afforded to other groups, it is difficult to know whether this group is treated favourably compared with other employees, and it is possible that managers (who are excluded from the above) might obtain more training than the largest occupational group. Perhaps surprisingly, sales is most commonly reported LOG (24.4\% of workplaces), followed by routine unskilled (14.6\%), administrative and clerical (14.2\%) and operative and assembly (11.5\%). The least common LOGs are professional (7.5\%), associate professional and technical (7.9\%) and caring, leisure and personal service (9.7\%). The size of the LOG also varies, from $11 \%$ of all employees in some workplaces, to $100 \%$ in others, with a mean of 65\%. However, in average, the gender and full-time/part-time status of the look similar to those for the entire workforce. Of course, in some workplaces LOG compositions differ substantially from their corresponding workforce compositions, although the semiinterquartile range for this difference is between -6 and +8 percentage points for the percentage male and -8 and +2 points for the percentage working full-time. As a referee has pointed out, some of the differences between establishments using the LOG measures might be a consequence of which group of workers the answers are based on; this is something we cannot rule out and which should be borne in mind subsequently.

In terms of workplace performance, we consider five measures in our analysis, the first being the absenteeism rate. Specifically, the management representative is asked, 'Over the last 12 
months what percentage of work days was lost through employee sickness or absence at this establishment?' Respondents are asked to exclude authorised leave of absence, employees away on secondment or courses, or days lost through industrial action.

Over the whole sample, managers reported an average of around 5\% of working days lost to sickness or absence. However, absence rates were higher in the public sector ${ }^{5}$. In contrast, lower rates are reported in Construction, perhaps reflecting the nature of contracts/employment in this sector. However, even these data reveal some very substantial variations: absence rates in the survey vary from zero to well in excess of $20 \%$.

The second measure of performance used is the quit rate, which is calculated using responses to the questions, 'In total, how many employees (full and part-time) were on the payroll at this establishment 12 months ago? And how many of these stopped working here because they left or resigned voluntarily?' Across the whole sample, the mean quit rate is around 16\%. However, this also varies substantially across sectors, for example $3.0 \%$ in Electricity, Gas and Water and over 30\% in Hotels and Restaurants. In contrast to the picture in terms of absence rates, sectors such as Education and Public Administration exhibit low levels of voluntary separations (7.3 and 2.7\% respectively). Again there are very substantial variations even within sectors; a small number of workplaces report $100 \%$ turnover during the year.

The remaining three performance measures are the respondent's assessment of their workplace's financial, labour productivity and quality of product or service relative to the rest of the industry. Various criticisms can be levelled at the subjective measures. First, they are usually based on the assessments of employee relations managers who may not always be in

\footnotetext{
${ }^{5}$ The Health and Safety Executive (HSE) however, indicate that this difference is almost entirely accounted for by compositional differences such as the gender and age profiles and organisational size. It may also reflect reporting differences.
} 
the best position to make such judgements. Second, they rely on management's ability to locate the performance of their own establishment in relation to an industry average which is left undefined. Third, it is not clear what measure of labour productivity is being considered output per head, value added or perhaps some measure of total factor productivity. Fourth, these subjective measures are ordinal in nature so there is no precise estimate of relative position. Finally, individuals may not measure things in precisely the same way and tend on the whole to be over-optimistic in the sense that most of them think their establishment is above average. Nevertheless, earlier studies have found, for example, that financial performance is a good measure of whether a workplace is likely to close or not (see Machin and Stewart, 1996).

The figures in Tables 1 and 2 are consistent with the findings of Tamkin et al. (2004) who note that most training periods are short (less than five days per year). In this survey, much of it is driven by statutory requirements such as health and safety rather than business needs, and only about half of it leads to formal qualifications. This is further supported when we examine the content and objectives of the training. The management questionnaire contains questions in these domains. ${ }^{6}$ The distribution of responses is shown in Table 3. The options are not mutually exclusive so members of the largest occupational group can receive more that one type of training. The most common type of training is health and safety training which as noted above, tends to be statutory. By far the most common training objectives are to extend or improve the skills employees have for their current job.

Returning to Table 2, one of the points to make about the figures is that training tends to be associated with lower quit rates (albeit only weakly so in panel (c)). Strangely, the converse

\footnotetext{
${ }^{6}$ Unfortunately no corresponding questions exist in the employee questionnaire and so we are unable to test whether the content or objectives of the training has an effect on job satisfaction.
} 
is true for the absence rate, but this may be influenced by the industrial composition of training and absence. For example, the public sector has generous sick pay schemes and high rates of training. The subjective measures of financial performance and labour productivity are positively correlated with the training measures. Of course, this is only a bivariate analysis and it is possible other variables are the real drivers of the results presented in Table 2.

Another notable feature from Tables 1 and 2 is the difference in implied training rates between managers' and workers' responses. Of course, part of the difference is due to the wording of the questions: the employee question explicitly excludes health and safety training whereas the employer question does not. Similarly, the management questionnaire focuses on experiences members of the largest occupational group whilst the employee questionnaire is based on a random sample of employees. One possible source of difference might be due to induction training which would only be given to new employees.

Table 4 details the differences in satisfaction from individual responses for each of the job satisfaction indicators, split according to whether a worker received any training during the previous 12 months. We then test whether the mean reported level of satisfaction for these groups is significantly different. Two features stand out. The first is that mean satisfaction levels vary across the different dimensions: perhaps unsurprisingly, pay exhibits the lowest mean (2.92) by some distance relative to the other indicators, with training being the next lowest (3.50). Overall work appears to have substantial intrinsic value to employees, with high scores being reported for autonomy, achievement and the work itself. The second feature to highlight is that those who have received training in the past year are significantly more satisfied on all of the measures relative to those who have not. While this would 
perhaps be unsurprising on the training dimension, it is evident that the higher mean satisfaction scores among training recipients extend to other dimensions not directly associated with training. Of course, training may facilitate greater autonomy/initiative, improve pay and be associated with greater job security, so this outcome should not be entirely unexpected. Nonetheless, the positive impact of training on these other measures of job satisfaction is important.

\section{Econometric Methodology}

To estimate the effect of training on the various indicators of satisfaction we make the commonly used assumption that satisfaction is measured by some unobservable latent variable $\mathrm{Y}^{*}$ which is determined as $\mathrm{Y}^{*}=\mathrm{X} \beta+\mathrm{u}$ where $\mathrm{X}$ is a matrix of dimension $\mathrm{K} \times \mathrm{K}(\mathrm{K}$ being the number of explanatory variables, which in this framework does not include a constant), $\beta$ is a $\mathrm{K} \times 1$ matrix of coefficients and $\mathrm{u}$ is a vector of disturbance terms.

Let $\alpha_{1}<\alpha_{2}<\ldots<\alpha_{\mathrm{J}-1}$ be unknown cut points or threshold parameters. In this framework, the observed response, $\mathrm{Y}$, will take the value 1 if $\mathrm{Y}^{*} \leq \alpha_{1}$ while

$$
\begin{aligned}
& \mathrm{Y}=2 \text { if } \alpha_{1}<\mathrm{Y}^{*} \leq \alpha_{2} \\
& \mathrm{Y}=3 \text { if } \alpha_{2}<\mathrm{Y}^{*} \leq \alpha_{3} \\
& \cdots \\
& \mathrm{Y}=\mathrm{J} \text { if } \alpha_{\mathrm{J}-1}<\mathrm{Y}^{*}
\end{aligned}
$$

where $\mathrm{J}$ is the number of alternative responses.

Denoting the cumulative density function of $\mathrm{u}$ by $\mathrm{F}($.$) , then the conditional distribution of \mathrm{Y}$ is given by the response probabilities:

$$
\mathrm{P}(\mathrm{Y}=1 \mid \mathrm{X})=\mathrm{P}\left(\mathrm{Y}^{*} \leq \alpha_{1} \mid \mathrm{X}\right)=\mathrm{P}\left(\mathrm{X} \beta+\mathrm{u} \leq \alpha_{1} \mid \mathrm{X}\right)=\mathrm{F}\left(\alpha_{1}-\mathrm{X} \beta\right)
$$




$$
\begin{aligned}
& \mathrm{P}(\mathrm{Y}=2 \mid \mathrm{X})=\mathrm{P}\left(\alpha_{1}<\mathrm{Y}^{*} \leq \alpha_{2} \mid \mathrm{X}\right)=\mathrm{P}\left(\alpha_{1}<\mathrm{X} \beta+\mathrm{u} \leq \alpha_{2} \mid \mathrm{X}\right)=\mathrm{F}\left(\alpha_{2}-\mathrm{X} \beta\right)-\mathrm{F}\left(\alpha_{1}-\mathrm{X} \beta\right) \\
& \mathrm{P}(\mathrm{Y}=3 \mid \mathrm{X})=\mathrm{P}\left(\alpha_{2}<\mathrm{Y}^{*} \leq \alpha_{3} \mid \mathrm{X}\right)=\mathrm{P}\left(\alpha_{2}<\mathrm{X} \beta+\mathrm{u} \leq \alpha_{3} \mid \mathrm{X}\right)=\mathrm{F}\left(\alpha_{3}-\mathrm{X} \beta\right)-\mathrm{F}\left(\alpha_{2}-\mathrm{X} \beta\right) \\
& \cdots \\
& \mathrm{P}(\mathrm{Y}=\mathrm{J}-1 \mid \mathrm{X})=\mathrm{P}\left(\alpha_{\mathrm{J}-2}<\mathrm{Y}^{*} \leq \alpha_{\mathrm{J}-1} \mid \mathrm{X}\right)=\mathrm{P}\left(\alpha_{\mathrm{J}-2}<\mathrm{X} \beta+\mathrm{u} \leq \alpha_{\mathrm{J}-1} \mid \mathrm{X}\right)=\mathrm{F}\left(\alpha_{\mathrm{J}-1}-\mathrm{X} \beta\right)-\mathrm{F}\left(\alpha_{\mathrm{J}-2}-\mathrm{X} \beta\right) \\
& \mathrm{P}(\mathrm{Y}=\mathrm{J} \mid \mathrm{X})=\mathrm{P}\left(\alpha_{\mathrm{J}-1}<\mathrm{Y}^{*} \mid \mathrm{X}\right)=\mathrm{P}\left(\alpha_{\mathrm{J}-1}<\mathrm{X} \beta+\mathrm{u} \mid \mathrm{X}\right)=1-\mathrm{F}\left(\alpha_{\mathrm{J}-1}-\mathrm{X} \beta\right)
\end{aligned}
$$

The parameters $\alpha$ and $\beta$ can be estimated by maximising the log-likelihood function summed over $\mathrm{n}$ individuals (indexed by $\mathrm{i}$ ) as:

$$
\log L=\sum_{\mathrm{i}=1}^{\mathrm{n}} \sum_{\mathrm{j}=1}^{\mathrm{J}} \mathrm{D}_{\mathrm{ij}} \log \left[\mathrm{P}\left(\mathrm{Y}_{\mathrm{i}}=\mathrm{j}\right)\right]
$$

where $D_{i j}=\left\{\begin{array}{c}1 \text { if } Y_{i}=j \\ 0 \text { otherwise }\end{array}\right.$ for $i=1, \ldots, n$ and $j=1, \ldots J$

Assuming a standard normal distribution for u gives the ordered probit model. In our context the estimation results are calculated using weights equal to $1 /$ (probability of selection and response) to bring the profiles of the achieved samples of workplaces and employees into line with the profiles of the respective populations. The weights remove biases introduced by the sample selection and response process. Bias arises in the sample selection process in both the workplace and the employee surveys. In the workplace survey, large workplaces and those from small industries are over-represented relative to their population share, whilst in the employee data employees from small workplaces are over-represented. Variable response rates can also cause the achieved sample to be unrepresentative of the population. In the workplace survey, larger workplaces had a higher response rate on average than smaller workplaces, whilst in the employee survey men were less likely to respond than women. ${ }^{7}$

A similar approach might be used to model the subjective measures of performance but changing the definition of the latent variable $\mathrm{Y}^{*}$ from one which measures underlying job

\footnotetext{
${ }^{7}$ For more information on the WERS sample design see Section 2 of the WERS 2004 Technical Report (Chaplin et al., 2005). The derivation of weights is described in Section 7.
} 
satisfaction to one which determines subjective assessment of financial performance, labour productivity or quality of product or service. However, at the suggestion of a referee, the performance models use deviations from industry means as the basis of analysis, and we therefore estimate these using OLS. Again estimation is weighted to reflect the survey's complex non-random sampling structure discussed above.

\section{Results}

\section{Training and Job Satisfaction}

This first set of results considers the determinants of the satisfaction measures described above, with particular reference to individual training receipt, as measured both by incidence and by volume (number of days) in the previous 12 months. Each of the models includes an extensive range of control variables as listed in the notes to the tables. ${ }^{8}$ Thus, any training effect identified is robust to and exerts an independent effect from these additional controls. Results for these controls are however, generally well-established in the literature, and for the sake of parsimony are not reported in detail here, where the focus is on the training measures. Thus, for example and inter alia, males, disabled workers, more highly qualified employees, union members and those working in larger organisations are generally less satisfied, while the reverse is true for older workers and those at the higher end of the earnings distribution.

Results for the dimensions of job satisfaction described previously appear in Table 5 . In part (a) of the table we use the binary indicator of whether the individual has received training or not, whilst in part (b) we use the full set of alternative answers to the training question. As is immediately evident from Table 5(a), having received training in the previous 12 months is positively and significantly related to all seven indicators. The relationship is, as would be

\footnotetext{
${ }^{8}$ A full set of variable means is available from the authors on request.
} 
expected, especially strong when considering satisfaction with training received. Taken together, these results suggest that training, of the type considered here, improves both an individual's (perceived) job security and their pay, and also increases their work autonomy with a concomitant increase in the intrinsic, non-pecuniary rewards of the job such as sense of achievement etc. The literature on job satisfaction and pay suggests that workers are not just concerned with the absolute amount of pay they receive but also about where they are in the distribution of pay; generally, the higher in the distribution they are, the more satisfied individuals are (Clark and Oswald, 1996, Sloane et al. 2005). We test whether this comparative process is also applied to training by including a variable which measures the proportion of workers in the same workplace who placed themselves in higher categories when answering the training question (more training). Regardless of the measure of satisfaction considered, the higher the proportion of other workers receiving more training than the individual the less satisfied is the individual.

Part (b) of Table 5 shows that workers who receive very short amounts of training (less than one day) in the previous year are actually less satisfied on several dimensions than those who received no training at all. The rationale for this is unclear, but it may perhaps reflect the fact that receiving any training raises individuals' expectations, but that these are not fulfilled when only a very modest amount of training is provided. Alternatively, very short volumes may be associated with particular types of training which reflect a more regimented, bureaucratic approach to (at least some facets of) work, with a corresponding reduction in levels of satisfaction for measures such as achievement and autonomy.

We then included several interaction terms to examine if training has a different effect on the satisfaction of different sets of workers. The first interaction we consider is between gender 
and training. For all of the direct measures, the interaction term is significant at the 5\%level. This suggests that training has a greater impact on the job satisfaction of men than of women. We confirm this by running separate estimations for males and females. For females, receiving training does not improve satisfaction with initiative, influence nor the work itself. In contrast, the receipt of training improves satisfaction across all domains for men.

Next we consider an interaction between age and training. We might expect younger workers to be more appreciative of training since they will have longer to reap the benefits of training. However, the interaction term is only significant for workers in their thirties. One explanation for this is that workers in this age group have found the career they wish to pursue and are being trained in the occupation they wish to stay in.

The interaction terms are also significant for those whose tenure is either 2 to less than 5 years or 5 to less than 10 years. One explanation for this might be that workers in these categories have received their initial or induction training and are now receiving training which is more relevant to their job. It may also be that workers in these groups have established themselves within that workplace and have more discretion on the type of training they take. Interaction dummies between training and highest level of qualification reveal that training has the biggest impact on satisfaction with training for those individuals whose highest qualification is 2 or more 'A' levels, first degree or postgraduate degree or their equivalents. The interaction terms are not significant at conventional levels for the other satisfaction measures. We also find that none of interactions between the training variable and the variable indicating the match between worker's skills and the skills required to the job are statistically significant. Thus, it appears that whilst training does increase the 
satisfaction of workers, there is no extra effect for those workers whose skill levels are below (or above) those required to do their job.

\section{Establishment Performance}

We now turn to the question whether training affects workplace performance either directly or indirectly through its affect on job satisfaction. As many establishment performance indicators differ substantially between sectors we use differences from sector means as the basis for analysis for the dependent variable and covariates in order to ensure that level differences between sectors do not dominate the results. This procedure may also reduce the problem of differences between the qualification groups considered. We estimate three equations for each measure of performance, the difference between them being how we measure training. The indicators of satisfaction represent workplace means. The results of these estimations are shown in Tables 6 and 7. Also presented in the table are two Wald tests. The first tests whether the satisfaction variables are jointly significant i.e. that all the coefficients are not all jointly equal to zero, the second whether the training variables are jointly significant ${ }^{9}$. To ensure consistency with subsequent estimation, the reported results all relate to a slightly smaller sample where 3 or more observations on individual employees were available for each workplace ${ }^{10}$. Results are qualitatively similar when using the larger sample. All the estimated models include a range of control variables as detailed in the notes to each table. Apart from those listed in the notes we also include measures of the average highest qualification level of workers and measure of the proportion of workers who are overskilled relative to the skills needed to do the job and a corresponding measure for the proportion who are underskilled, the reference group being the proportion who skills match

\footnotetext{
${ }^{9}$ We do not present a result for the proportion based training measure as in this instance there is a single variable and the test is equivalent to a t-test.

${ }^{10}$ This is a crude and simple approximation to the 60 per cent threshold recommended in the WERS Technical Report and which preserves as many workplaces in the sample as possible.
} 
those required to the job. These measures are both derived from the employee dataset. The specification used to model financial performance also includes a series of dummy variables derived from the question that asks which of these alternatives presented corresponds most closely to the management respondents' interpretation of financial performance? The options given are profit, value added, sales, fees, budget, costs, expenditure, stock market indicators and other. Subsequent questions about financial performance are then asked in terms of the option selected.

The main finding from Tables 6 and 7 is that the satisfaction variables are jointly significantly associated with all the performance measures considered. While there is a negative association between the proportion trained and quit and absence rates, this relationship is typically not significant. The relationship between the training measures and financial performance and productivity follows a similar (this time positive) pattern, but there is a negative and significant relationship between the aggregate proportion trained and product quality, which suggests in this case the causation goes the other way, with low quality inducing more training.

Which measures of satisfaction are driving these results is unclear. Taking the objective measure first, the quit rate is positively related to satisfaction with initiative but is negatively associated with the satisfaction with influence. In contrast, satisfaction with initiative is negatively related to the absence rate. Considering the subjective performance measures, satisfaction with achievement is positively related to assessments of financial performance and labour productivity. The positive association between job security and financial performance highlights one of the limitations of this analysis. It may be that workers who are secure in their jobs put more effort into their wok, perhaps undertaking less on the job search, 
and are therefore more productive, which in turn improves the financial performance of the workplace. However, the causation may run in the opposite direction in that workers in firms which are performing well feel more secure in their jobs. Another problem using this approach is the high degree of collinearity between the measures of satisfaction as workers who are satisfied on one dimension are more likely to be satisfied on other dimensions. Table 8 shows the correlation matrix of direct satisfaction indicators. Similarly, the analysis conducted in the earlier section suggests that there is a close relationship between the training measures and satisfaction measures.

In an attempt to address the first of these problems, we combine the satisfaction measures into a single index (S) according to $S=\sum_{k=1}^{7} \theta_{k} s_{k}$ where $s_{k}$ denotes the $k^{\text {th }}$ component of the index and $\theta_{\mathrm{k}}$ the associated weight. Rather than assign weights on an ad hoc basis, we adopt a data reduction approach used by inter alia Machin (1991) in which the weights are derived from the scaled first principal component of the variance-covariance matrix of the elements of the index and normalised such that they sum to unity. The first principal component accounts for almost exactly half (49.3 per cent) of the covariance; the second in contrast, accounts for just 15.3 per cent, suggesting that restricting attention to the first principal component is appropriate. Table 9 documents the (scaled) weights used in constructing the composite measure. Interestingly, these are all positive and relatively similar in magnitude, ranging from 0.157 for 'influence' to 0.123 for 'security'.

The results using the composite satisfaction measure are presented in Tables 10 and 11. Quit rates are higher in workplaces where a higher proportion of workers are overskilled. This probably reflects overskilled workers seeking jobs which match their skills more closely. 
Similarly, the higher quit rates in firms with higher average education levels might be due to the wider outside opportunities available to more educated workers. As we would expect, absence rates are significantly inversely related to the satisfaction measure, although the quit rate is not. The training measures from the employer questionnaire are inversely rated to the quit rate and the absence rate, albeit less strongly in the latter case. Each of the subjective performance measures is positively and significantly related to the composite satisfaction measure, supporting the hypothesis that higher job satisfaction is associated with improved workplace performance. The two domains could be mutually reinforcing with workers deriving more satisfaction from working in a successful organisation. Having a high proportion of under-skilled workers is now associated with better financial performance, and the over-skilling variable loses significance. Consistent with human capital theory, higher average education levels are positively related to higher labour productivity. The incidence and duration based measures of training are both positively related to financial performance and labour productivity, although a more mixed pattern is evident for quality.

Up to this point we have treated training as a homogenous process. Of course, this is highly unrealistic as training can vary in its content and its objectives. We begin to rectify this by including a series of binary variables modelling the training content and objective variables tabulated in Table 3. For reasons of space the detailed results are not presented here. Examining each performance measures in turn, the quit rate is negatively related to the customer service/liaison training. This may be because this type of training occurs most frequently in industries where there is a high turnover over workers e.g. wholesale and retail. Communications training is associated with lower absence rates. Training in the operation of new equipment is associated with lower financial performance. Whilst training in problem solving is positively related to higher perceived labour productivity. Not surprisingly, training 
about quality control procedures is associated with higher perceived quality of goods and service. Turning to training objectives, training which provides the skills needed for employees to move to different jobs is the only objective which raises performance. Strangely, training which increase employees' understanding of, or commitment to, the organisation is associated with higher absenteeism. However, the introduction of this type of training might be a measure used by management in response to high absenteeism.

\section{Conclusions}

This paper attempts to answer three main questions. First, does training affect job satisfaction? Second, does training affect workplace performance either directly or indirectly through its affect on job satisfaction? Third, does job satisfaction itself affect workplace performance? We have considered five different measures of performance - the absenteeism rate, the quit rate and three subjective measures on the part of managers - financial performance, labour productivity and product quality.

We have found clear evidence that training is positively and significantly associated with job satisfaction and that job satisfaction is also positively and significantly associated with the workplace performance on most measures of performance. The relationship between performance and training is more complicated, with the relationships depending on the features of training and measure of performance considered. However, given the problem of endogeneity these are better regarded as lower bound estimates. Employers may be able to improve establishment performance by increasing the volume of training and taking action to raise the job satisfaction of the workforce, but to succeed in this they also need to pay attention to the quantity and type of training offered. Training of less than two days appears to have no beneficial effect on financial performance, productivity or product quality, though between one and two days does appear to lower quit and absence rates. Only when training 
covers a large proportion of the workforce does it appear to have beneficial effects on financial performance and productivity. There is tentative evidence that having a higher proportion of over-skilled workers is associated with improved financial performance, but also with a higher quit rate. If training could ensure that skills were better utilised this might reduce the propensity to quit. Profiling of workers and their training requirements may, therefore, pay dividends. 
Table 1: Distribution of training (employee questionnaire)

Apart from health and safety training, how much training have you had during the last 12 months, either paid for or organised by your employer?

\begin{tabular}{|l|c|}
\hline Days & $\%$ \\
\hline None & 36.79 \\
\hline less than 1 day & 9.43 \\
\hline 1 to less than 2 days & 14.65 \\
\hline 2 to less than 5 days & 21.26 \\
\hline 5 to less than 10 days & 9.62 \\
\hline 10 days or more & 8.24 \\
\hline
\end{tabular}


Table 2: Distribution of training and correlation with performance indicators (employer questionnaire)

(a) What proportion of experienced members of the largest occupational group have been given time off from their normal daily work duties to undertake training over the past 12 months?

\begin{tabular}{|l|c|c|c|c|c|c|}
\hline & $\%$ & $\begin{array}{c}\text { Quit } \\
\text { rate (\%) }\end{array}$ & $\begin{array}{c}\text { Absence } \\
\text { rate (\%) }\end{array}$ & $\begin{array}{c}\text { Financial } \\
\text { performance }\end{array}$ & $\begin{array}{c}\text { Labour } \\
\text { productivity }\end{array}$ & Quality \\
\hline $0 \%$ & 20.47 & 20.77 & 3.76 & 3.33 & 3.50 & 4.07 \\
\hline $1-19 \%$ & 15.16 & 14.35 & 3.72 & 3.53 & 3.59 & 4.07 \\
\hline $20-39 \%$ & 9.91 & 18.21 & 4.24 & 3.48 & 3.43 & 4.01 \\
\hline $40-59 \%$ & 9.85 & 20.22 & 3.66 & 3.34 & 3.38 & 3.80 \\
\hline $60-79 \%$ & 7.10 & 13.66 & 4.65 & 3.55 & 3.57 & 4.02 \\
\hline $80-99 \%$ & 6.92 & 14.14 & 3.34 & 3.46 & 3.43 & 3.80 \\
\hline $100 \%$ & 30.60 & 11.91 & 5.85 & 3.60 & 3.68 & 4.05 \\
\hline $\begin{array}{l}\text { Pearson } \\
\begin{array}{l}\text { Correlation } \\
\text { Coefficient }\end{array}\end{array}$ & -0.1472 & 0.1108 & 0.0930 & 0.0687 & -0.0278 \\
\hline $\begin{array}{l}\text { t-test of } \\
\text { independence } \\
\text { P-value }\end{array}$ & & 0.0008 & 0.0112 & 0.0233 & 0.1262 & 0.5029 \\
\hline
\end{tabular}

(b) On average, how many days of training did experienced members of largest occupational group spend on training?

\begin{tabular}{|l|c|c|c|c|c|c|}
\hline Days & $\%$ & $\begin{array}{c}\text { Quit } \\
\text { rate (\%) }\end{array}$ & $\begin{array}{c}\text { Absence } \\
\text { rate (\%) }\end{array}$ & $\begin{array}{c}\text { Financial } \\
\text { performance }\end{array}$ & $\begin{array}{c}\text { Labour } \\
\text { productivity }\end{array}$ & Quality \\
\hline None & 22.41 & 21.45 & 3.67 & 3.35 & 3.48 & 4.06 \\
\hline$<1$ & 4.25 & 15.22 & 4.84 & 3.55 & 3.45 & 3.96 \\
\hline 1 to $<2$ & 19.50 & 15.52 & 3.63 & 3.36 & 3.38 & 3.91 \\
\hline 2 to $<5$ & 29.07 & 14.51 & 4.36 & 3.55 & 3.66 & 4.03 \\
\hline 5 to $<10$ & 13.62 & 11.54 & 6.04 & 3.47 & 3.54 & 3.98 \\
\hline$>=10$ & 11.15 & 14.98 & 5.15 & 3.77 & 3.77 & 4.12 \\
\hline $\begin{array}{l}\text { Pearson } \\
\text { Correlation } \\
\text { Coefficient }\end{array}$ & & -0.1392 & 0.0898 & 0.1300 & 0.1106 & 0.0145 \\
\hline $\begin{array}{l}\text { t-test of } \\
\text { independence } \\
\text { P-value }\end{array}$ & & 0.0004 & 0.0446 & 0.0013 & 0.0004 & 0.7264 \\
\hline
\end{tabular}

(c) Proportion of employees who have received training

\begin{tabular}{|l|c|c|c|c|c|}
\hline & $\begin{array}{c}\text { Quit } \\
\text { rate (\%) }\end{array}$ & $\begin{array}{c}\text { Absence } \\
\text { rate (\%) }\end{array}$ & $\begin{array}{c}\text { Financial } \\
\text { performance }\end{array}$ & $\begin{array}{c}\text { Labour } \\
\text { productivity }\end{array}$ & Quality \\
\hline $\begin{array}{l}\text { Pearson } \\
\text { Correlation } \\
\text { Coefficient }\end{array}$ & -0.0874 & 0.1154 & 0.0596 & 0.0371 & -0.0764 \\
\hline $\begin{array}{l}\text { t-test of } \\
\text { independence } \\
\text { P-value }\end{array}$ & 0.0674 & 0.0014 & 0.2188 & 0.6672 & 0.0874 \\
\hline & $\begin{array}{c}\text { Quit } \\
\text { rate (\%) }\end{array}$ & $\begin{array}{c}\text { Absence } \\
\text { rate (\%) }\end{array}$ & $\begin{array}{c}\text { Financial } \\
\text { performance }\end{array}$ & $\begin{array}{c}\text { Labour } \\
\text { productivity }\end{array}$ & Quality \\
\hline All & 15.81 & 4.46 & 3.49 & 3.55 & 4.01 \\
\hline
\end{tabular}


Table 3: Training content and objectives

\begin{tabular}{|l|c|}
\hline & $\begin{array}{l}\text { Percentage of firms } \\
\text { (conditional on at least } \\
\text { one member of the } \\
\text { largest occupational } \\
\text { group receiving training) }\end{array}$ \\
\hline Training Content & 43 \\
\hline Computing skills & 39 \\
\hline Communication & 45 \\
\hline Teamworking & 31 \\
\hline Leadership skills & 47 \\
\hline Operation of new equipment & 42 \\
\hline Customer service/liaison & 68 \\
\hline Health and safety & 20 \\
\hline Problem-solving methods & 21 \\
\hline Equal opportunities & 18 \\
\hline Reliability and working to deadlines & 34 \\
\hline Quality control procedures & \\
\hline \multicolumn{2}{|l|}{} \\
\hline Training Objectives & 85 \\
\hline Improve the skills already used by employees in their current jobs & 82 \\
\hline Extend the range of skills used by employees in their current jobs & 34 \\
\hline Provide the skills needed for employees to move to different jobs & 13 \\
\hline Obtain Investors in People status or other quality standard & 47 \\
\hline Increase employees' understanding of, or commitment to, the organisation & 10 \\
\hline Other objective & \\
\hline
\end{tabular}

Table 4: Tests of difference in average satisfaction between those receiving and not receiving training in previous twelve months

\begin{tabular}{|l|c|c|c|}
\hline & \multicolumn{2}{|c|}{ Mean response for those who: } & \\
\hline & Received training & Did not receive training & $\mathrm{t}$-value \\
\hline Achievement & 3.80 & 3.68 & $6.67^{* * *}$ \\
\hline Initiative & 3.85 & 3.73 & $6.55^{* * *}$ \\
\hline Influence & 3.58 & 3.49 & $5.42^{* * *}$ \\
\hline Training & 3.50 & 3.02 & $21.17^{* * *}$ \\
\hline Pay & 2.92 & 2.76 & $7.07^{* * *}$ \\
\hline Job security & 3.64 & 3.53 & $4.97^{* * *}$ \\
\hline Work itself & 3.82 & 3.70 & $6.67^{* * *}$ \\
\hline
\end{tabular}

Notes: * denotes significantly different at the $10 \%$ level, ${ }^{* *}$ at the $5 \%$ level and ${ }^{* * *}$ at the $1 \%$. 
Table 5: Job satisfaction measures

\begin{tabular}{|l|l|l|l|l|l|l|l|}
\hline \multicolumn{2}{|c|}{ (a) Ordered probit estimates of job satisfaction dimensions - training incidence } \\
\hline & $\begin{array}{c}\text { Achieve- } \\
\text { ment }\end{array}$ & Initiative & Influence & Training & Pay & $\begin{array}{c}\text { Job } \\
\text { security }\end{array}$ & \multicolumn{1}{c|}{$\begin{array}{l}\text { Work } \\
\text { itself }\end{array}$} \\
\hline Training & $0.130^{* * *}$ & $0.107^{* * *}$ & $0.117^{* * *}$ & $0.566^{* * *}$ & $0.129^{* * *}$ & $0.162^{* * *}$ & $0.148^{* * *}$ \\
incidence & $(0.024)$ & $(0.024)$ & $(0.023)$ & $(0.023)$ & $(0.023)$ & $(0.024)$ & $(0.024)$ \\
\hline More & $-0.113^{* * *}$ & $-0.121^{* * *}$ & $-0.108^{* * *}$ & $-0.273^{* * *}$ & $-0.095^{* * *}$ & $-0.076^{* * *}$ & $-0.113^{* * *}$ \\
training & $(0.018)$ & $(0.018)$ & $(0.019)$ & $(0.019)$ & $(0.019)$ & $(0.018)$ & $(0.019)$ \\
\hline
\end{tabular}

(b) Ordered probit estimates of job satisfaction dimensions - training volume (number of days)

\begin{tabular}{|l|l|l|l|l|l|l|l|}
\hline & $\begin{array}{c}\text { Achieve- } \\
\text { ment }\end{array}$ & Initiative & Influence & Training & \multicolumn{1}{|c|}{ Pay } & $\begin{array}{c}\text { Job } \\
\text { security }\end{array}$ & \multicolumn{1}{c|}{$\begin{array}{l}\text { Work } \\
\text { itself }\end{array}$} \\
\hline Less than & $-0.070^{*}$ & $-0.126^{* * *}$ & $-0.071^{*}$ & $0.113^{* * *}$ & 0.008 & -0.006 & -0.028 \\
1 day & $(0.041)$ & $(0.043)$ & $(0.042)$ & $(0.040)$ & $(0.041)$ & $(0.040)$ & $(0.041)$ \\
\hline 1 to $<2$ & 0.025 & 0.030 & $0.067^{* *}$ & $0.385^{* * *}$ & $0.093^{* * *}$ & $0.094^{* * *}$ & $0.060^{*}$ \\
days & $(0.032)$ & $(0.033)$ & $(0.032)$ & $(0.032)$ & $(0.032)$ & $(0.031)$ & $(0.032)$ \\
\hline 2 to $<5$ & $0.203^{* * *}$ & $0.186^{* * *}$ & $0.175^{* * *}$ & $0.639^{* * *}$ & $0.173^{* * *}$ & $0.195^{* * *}$ & $0.226^{* * *}$ \\
days & $(0.031)$ & $(0.031)$ & $(0.031)$ & $(0.031)$ & $(0.031)$ & $(0.031)$ & $(0.032)$ \\
\hline 5 to $<10$ & $0.210^{* * *}$ & $0.226^{* * *}$ & $0.167^{* * *}$ & $0.912^{* * *}$ & $0.161^{* * *}$ & $0.269^{* * *}$ & $0.187^{* * *}$ \\
days & $(0.041)$ & $(0.040)$ & $(0.040)$ & $(0.040)$ & $(0.039)$ & $(0.040)$ & $(0.042)$ \\
\hline 10 days & $0.426 * * *$ & $0.325^{* * *}$ & $0.329^{* * *}$ & $1.290^{* * *}$ & $0.250^{* * *}$ & $0.388^{* * *}$ & $0.393^{* * *}$ \\
or more & $(0.046)$ & $(0.044)$ & $(0.041)$ & $(0.046)$ & $(0.044)$ & $(0.043)$ & $(0.045)$ \\
\hline More & -0.027 & -0.027 & -0.032 & $-0.078^{* * *}$ & $-0.047 * *$ & -0.005 & $-0.039^{*}$ \\
training & $(0.022)$ & $(0.023)$ & $(0.023)$ & $(0.023)$ & $(0.023)$ & $(0.022)$ & $(0.022)$ \\
\hline
\end{tabular}

Notes: Standard errors in parentheses. * denotes significant at the $10 \%$ level, $* *$ at the $5 \%$ level and ${ }^{* * *}$ at the 1\%. All models include individual controls for gender, age, marital status, ethnicity, disability, tenure, fixed term employment, temporary job status, hours of work, use of computers in job, levels of skills relative to those needed in job, highest academic qualification, vocational qualification, occupation, gender balance of job, union membership and earnings (banded), plus employer controls for workplace size, organisation size, workplace age, industry, proportions of workforce aged less than 21, over 50, female, union members, from ethnic minority, with disabilities, working part-time, on fixed term contracts, agency staff and the presence of briefing groups discussing training, JCCs discussing training and meeting groups discussing training. 
Table 6: Training and mean satisfaction level as determinants of workplace performance OLS estimates - deviations from industry means

\begin{tabular}{|c|c|c|c|c|c|c|}
\hline \multirow{3}{*}{$\begin{array}{l}\text { Average highest } \\
\text { qualification }\end{array}$} & \multicolumn{3}{|c|}{ Quit rate } & \multicolumn{3}{|c|}{ Absence rate } \\
\hline & 0.008 & 0.007 & 0.008 & $0.401^{*}$ & 0.331 & 0.299 \\
\hline & $(0.007)$ & $(0.007)$ & $(0.007)$ & $(0.239)$ & $(0.241)$ & $(0.252)$ \\
\hline \multirow[t]{2}{*}{ \% Overskilled } & $0.058^{*}$ & 0.055 & $0.062^{*}$ & -0.851 & -0.590 & -0.666 \\
\hline & $(0.035)$ & $(0.035)$ & $(0.035)$ & $(0.973)$ & $(0.975)$ & $(0.979)$ \\
\hline \multirow[t]{2}{*}{ \% Underskilled } & 0.080 & 0.101 & 0.067 & $-3.139 *$ & $-3.362^{*}$ & -2.878 \\
\hline & $(0.065)$ & $(0.065)$ & $(0.077)$ & $(1.847)$ & $(1.932)$ & $(2.232)$ \\
\hline \multicolumn{7}{|c|}{ Satisfaction indicators } \\
\hline \multirow[t]{2}{*}{ Achievement } & 0.028 & 0.030 & 0.029 & 2.104 & 2.049 & 2.053 \\
\hline & $(0.023)$ & $(0.022)$ & $(0.023)$ & $(1.323)$ & $(1.340)$ & $(1.355)$ \\
\hline \multirow[t]{2}{*}{ Initiative } & $0.085 * * *$ & $0.081^{* * *}$ & $0.088 * * *$ & -1.068 & -1.112 & -0.996 \\
\hline & $(0.032)$ & $(0.031)$ & $(0.031)$ & $(0.942)$ & $(0.956)$ & $(0.933)$ \\
\hline \multirow[t]{2}{*}{ Influence } & $-0.093 * * *$ & $-0.085 * *$ & $-0.093 * * *$ & -1.423 & -1.412 & -1.441 \\
\hline & $(0.033)$ & $(0.034)$ & $(0.034)$ & $(1.230)$ & $(1.212)$ & $(1.212)$ \\
\hline \multirow[t]{2}{*}{ Training } & 0.002 & -0.002 & 0.001 & 0.118 & 0.406 & 0.048 \\
\hline & $(0.015)$ & $(0.015)$ & $(0.016)$ & $(0.591)$ & $(0.588)$ & $(0.547)$ \\
\hline \multirow[t]{2}{*}{ Pay } & -0.002 & -0.001 & -0.001 & $-1.155^{* *}$ & $-1.154 *$ & $-1.154 * *$ \\
\hline & $\begin{array}{l}(0.016) \\
(0.0)\end{array}$ & $\begin{array}{l}(0.016) \\
\end{array}$ & $(0.016)$ & $(0.577)$ & $(0.597)$ & $(0.585)$ \\
\hline \multirow{2}{*}{ Job security } & 0.001 & -0.001 & 0.002 & -0.891 & $-1.235^{*}$ & $-1.130 *$ \\
\hline & $(0.015)$ & $(0.015)$ & $(0.015)$ & $(0.661)$ & $(0.681)$ & $(0.679)$ \\
\hline \multirow[t]{2}{*}{ Work itself } & -0.030 & -0.034 & -0.031 & -0.068 & 0.093 & 0.097 \\
\hline & $(0.027)$ & $(0.028)$ & $(0.027)$ & $(0.953)$ & $(0.986)$ & $(0.983)$ \\
\hline \multicolumn{7}{|c|}{ Training measures } \\
\hline \multicolumn{7}{|c|}{ Proportion of LOG trained } \\
\hline \multirow[t]{2}{*}{$1-19 \%$} & $-0.055 * *$ & & & -0.951 & & \\
\hline & $(0.026)$ & & & $(0.825)$ & & \\
\hline \multirow[t]{2}{*}{$20-39 \%$} & -0.018 & & & -1.051 & & \\
\hline & $(0.032)$ & & & $(1.014)$ & & \\
\hline \multirow[t]{2}{*}{$40-59 \%$} & -0.022 & & & $-1.946 * *$ & & \\
\hline & $(0.030)$ & & & $(0.898)$ & & \\
\hline \multirow[t]{2}{*}{$60-79 \%$} & -0.026 & & & -0.380 & & \\
\hline & $(0.029)$ & & & $(1.241)$ & & \\
\hline \multirow[t]{2}{*}{$70-99 \%$} & $-0.057^{*}$ & & & $-2.514 * *$ & & \\
\hline & $(0.032)$ & & & $(1.037)$ & & \\
\hline \multirow[t]{2}{*}{$100 \%$} & $-0.048 * *$ & & & 0.137 & & \\
\hline & $(0.024)$ & & & $(0.994)$ & & \\
\hline \multicolumn{7}{|c|}{ Time LOG spend training (days) } \\
\hline$<1$ & & -0.039 & & & -0.285 & \\
\hline & & $(0.036)$ & & & $(1.327)$ & \\
\hline 1 to $<2$ & & $-0.065 * *$ & & & $-1.534^{*}$ & \\
\hline & & $(0.026)$ & & & $(0.840)$ & \\
\hline 2 to $<5$ & & $-0.055 * * *$ & & & -0.666 & \\
\hline & & $(0.021)$ & & & $(0.804)$ & \\
\hline 5 to $<10$ & & $-0.058 * *$ & & & 0.277 & \\
\hline & & $(0.026)$ & & & $(1.220)$ & \\
\hline$\geq 10$ & & -0.035 & & & -0.151 & \\
\hline & & $(0.026)$ & & & $(1.278)$ & \\
\hline
\end{tabular}




\begin{tabular}{|c|c|c|c|c|c|c|}
\hline \multirow{2}{*}{$\begin{array}{l}\text { Proportion of } \\
\text { employees trained }\end{array}$} & & & -0.020 & & & 0.856 \\
\hline & & & $(0.032)$ & & & (1.159) \\
\hline R-squared & 0.180 & 0.176 & 0.169 & 0.091 & 0.088 & 0.085 \\
\hline $\begin{array}{l}\text { Wald Test } \\
\mathrm{H}_{0} \text { : All } \\
\text { coefficients on } \\
\text { satisfaction } \\
\text { variables }=0\end{array}$ & 1.92 & 2.03 & 1.98 & 2.36 & 2.14 & 2.79 \\
\hline P-value & 0.0628 & 0.0488 & 0.0551 & 0.0215 & 0.0370 & 0.0069 \\
\hline $\begin{array}{l}\mathrm{H}_{0}: \text { All } \\
\text { coefficients on } \\
\text { training variables } \\
=0\end{array}$ & 1.14 & 1.81 & & 2.40 & 1.20 & \\
\hline P-value & 0.3372 & 0.1085 & & 0.0262 & 0.3050 & \\
\hline
\end{tabular}

Notes: * indicates significance at 10 per cent level; ** indicates significance at 5 per cent level and ${ }^{* * *}$ indicates significance at 1 per cent level. Standard errors in parentheses. All models include employer controls for workplace size, organisation size, industry, establishment age, proportions of workforce aged less than 21, over 50, from ethnic minority, with disabilities, working part-time, union members, on fixed term contracts, agency staff and the presence of performance related pay, payment by results and merit pay. LOG denotes largest occupational group. Mean composite satisfaction and mean proportion trained at workplace obtained from employee questionnaire. 
Table 7: Training and mean satisfaction level as determinants of workplace performance - OLS estimates - deviations from industry means

\begin{tabular}{|c|c|c|c|c|c|c|c|c|c|}
\hline \multirow[b]{2}{*}{ Average highest qualification } & \multicolumn{3}{|c|}{ Financial Performance } & \multicolumn{3}{|c|}{ Labour Productivity } & \multicolumn{3}{|c|}{ Quality } \\
\hline & $0.125^{*}$ & 0.111 & 0.124 & 0.031 & 0.025 & 0.037 & $0.052 * *$ & $0.048 *$ & $0.062 * *$ \\
\hline & $(0.072)$ & $(0.074)$ & $(0.076)$ & $(0.029)$ & $(0.029)$ & $(0.031)$ & $(0.025)$ & $(0.025)$ & $(0.025)$ \\
\hline \multirow[t]{2}{*}{ \% Overskilled } & $0.328 * *$ & $0.320 * *$ & $0.331 * *$ & 0.158 & 0.136 & 0.175 & -0.004 & 0.003 & -0.006 \\
\hline & $(0.156)$ & $(0.156)$ & $(0.156)$ & $(0.136)$ & $(0.135)$ & $(0.139)$ & $(0.132)$ & $(0.131)$ & $(0.130)$ \\
\hline \multirow[t]{2}{*}{ \% Underskilled } & 0.373 & 0.329 & $0.623^{*}$ & -0.226 & -0.261 & 0.204 & -0.192 & -0.150 & -0.468 \\
\hline & $(0.318)$ & $(0.352)$ & $(0.348)$ & $(0.411)$ & $(0.496)$ & $(0.357)$ & $(0.410)$ & $(0.386)$ & $(0.369)$ \\
\hline \multicolumn{10}{|l|}{ Satisfaction indicators } \\
\hline \multirow[t]{2}{*}{ Achievement } & $0.255^{* *}$ & $0.218 * *$ & $0.274 * *$ & $0.221^{*}$ & 0.172 & $0.247 * *$ & 0.013 & -0.016 & -0.046 \\
\hline & $(0.109)$ & $(0.108)$ & $(0.114)$ & $(0.122)$ & $(0.123)$ & $(0.123)$ & $(0.092)$ & $(0.091)$ & $(0.091)$ \\
\hline \multirow[t]{2}{*}{ Initiative } & 0.105 & 0.125 & 0.071 & 0.109 & 0.135 & 0.080 & 0.064 & 0.080 & 0.094 \\
\hline & $(0.137)$ & $(0.136)$ & $(0.140)$ & $(0.122)$ & $(0.120)$ & $(0.120)$ & $(0.115)$ & $(0.121)$ & $(0.114)$ \\
\hline \multirow[t]{2}{*}{ Influence } & $-0.356 * * *$ & $-0.360 * * *$ & $-0.352 * * *$ & -0.161 & -0.171 & -0.186 & -0.049 & -0.047 & -0.062 \\
\hline & $(0.130)$ & $(0.129)$ & $(0.132)$ & $(0.124)$ & $(0.122)$ & $(0.123)$ & $(0.104)$ & $(0.107)$ & $(0.105)$ \\
\hline \multirow[t]{2}{*}{ Training } & 0.044 & 0.062 & 0.053 & 0.110 & $0.118^{*}$ & $0.133^{*}$ & 0.078 & 0.081 & $0.123^{*}$ \\
\hline & $(0.069)$ & $(0.067)$ & $(0.074)$ & $(0.070)$ & $(0.068)$ & $(0.079)$ & $(0.062)$ & $(0.062)$ & $(0.064)$ \\
\hline \multirow[t]{2}{*}{ Pay } & $0.132 * *$ & $0.126 * *$ & $0.127 *$ & 0.089 & 0.079 & 0.083 & 0.004 & 0.000 & -0.018 \\
\hline & $(0.066)$ & $(0.063)$ & $(0.066)$ & $(0.065)$ & $(0.062)$ & $(0.064)$ & $(0.047)$ & $(0.047)$ & $(0.046)$ \\
\hline \multirow[t]{2}{*}{ Job security } & $0.200 * *$ & $0.169 * *$ & $0.178 * *$ & 0.039 & 0.022 & 0.017 & 0.088 & 0.070 & 0.091 \\
\hline & $(0.079)$ & $(0.077)$ & $(0.081)$ & $(0.083)$ & $(0.084)$ & $(0.084)$ & $(0.066)$ & $(0.064)$ & $(0.063)$ \\
\hline \multirow[t]{2}{*}{ Work itself } & -0.183 & -0.164 & -0.166 & -0.124 & -0.094 & -0.080 & 0.056 & 0.069 & 0.090 \\
\hline & $(0.121)$ & $(0.117)$ & $(0.123)$ & $(0.113)$ & $(0.112)$ & $(0.110)$ & $(0.106)$ & $(0.109)$ & $(0.108)$ \\
\hline \multicolumn{10}{|l|}{ Training measures } \\
\hline \multicolumn{10}{|l|}{ Proportion of LOG trained } \\
\hline \multirow[t]{2}{*}{$1-19 \%$} & 0.173 & & & 0.152 & & & -0.020 & & \\
\hline & $(0.105)$ & & & $(0.112)$ & & & $(0.096)$ & & \\
\hline \multirow[t]{2}{*}{$20-39 \%$} & 0.177 & & & -0.001 & & & -0.047 & & \\
\hline & $(0.122)$ & & & $(0.124)$ & & & $(0.101)$ & & \\
\hline \multirow[t]{2}{*}{$40-59 \%$} & 0.116 & & & -0.054 & & & $-0.269 * *$ & & \\
\hline & $(0.165)$ & & & $(0.146)$ & & & $(0.127)$ & & \\
\hline
\end{tabular}




\begin{tabular}{|c|c|c|c|c|c|c|c|c|c|}
\hline \multirow[t]{2}{*}{$60-79 \%$} & $0.246^{*}$ & & & 0.099 & & & -0.108 & & \\
\hline & $(0.133)$ & & & $(0.149)$ & & & $(0.136)$ & & \\
\hline \multirow[t]{2}{*}{$70-99 \%$} & 0.097 & & & -0.036 & & & $-0.263 * *$ & & \\
\hline & $(0.158)$ & & & $(0.176)$ & & & $(0.130)$ & & \\
\hline \multirow[t]{2}{*}{$100 \%$} & $0.297 * * *$ & & & $0.212 *$ & & & -0.038 & & \\
\hline & $(0.103)$ & & & $(0.114)$ & & & $(0.101)$ & & \\
\hline \multicolumn{10}{|l|}{ Time LOG spend training (days) } \\
\hline \multirow[t]{2}{*}{$<1$} & & 0.240 & & & 0.103 & & & -0.054 & \\
\hline & & $(0.200)$ & & & $(0.140)$ & & & $(0.156)$ & \\
\hline \multirow[t]{2}{*}{1 to $<2$} & & 0.043 & & & 0.007 & & & -0.155 & \\
\hline & & $(0.103)$ & & & $(0.116)$ & & & $(0.096)$ & \\
\hline \multirow[t]{2}{*}{2 to $<5$} & & $0.287 * * *$ & & & $0.209 *$ & & & -0.041 & \\
\hline & & $(0.098)$ & & & $(0.110)$ & & & $(0.094)$ & \\
\hline \multirow[t]{2}{*}{5 to $<10$} & & 0.151 & & & 0.092 & & & -0.051 & \\
\hline & & $(0.117)$ & & & $(0.124)$ & & & $(0.104)$ & \\
\hline \multirow[t]{2}{*}{$\geq 10$} & & $0.400 * * *$ & & & $0.361 * * *$ & & & 0.072 & \\
\hline & & $(0.120)$ & & & $(0.128)$ & & & $(0.103)$ & \\
\hline \multirow[t]{2}{*}{ Proportion of employees trained } & & & 0.106 & & & 0.033 & & & $-0.259 * *$ \\
\hline & & & $(0.138)$ & & & $(0.148)$ & & & $(0.128)$ \\
\hline R-squared & 0.130 & 0.141 & 0.119 & 0.090 & 0.094 & 0.078 & 0.084 & 0.073 & 0.078 \\
\hline $\begin{array}{l}\text { Wald Test } \\
\mathrm{H}_{0}: \text { All coefficients on satisfaction } \\
\text { variables }=0\end{array}$ & 4.21 & 3.59 & 3.95 & 2.38 & 1.94 & 2.26 & 1.74 & 1.45 & 2.15 \\
\hline P-Value & 0.0001 & 0.0008 & 0.0003 & 0.0205 & 0.0600 & 0.0277 & 0.0948 & 0.1812 & 0.0364 \\
\hline $\begin{array}{l}\mathrm{H}_{0}: \text { All coefficients on training } \\
\text { variables }=0\end{array}$ & 1.74 & 3.46 & & 1.54 & 2.48 & & 1.56 & 1.17 & \\
\hline P-Value & 0.1084 & 0.0041 & & 0.1611 & 0.0301 & & 0.1563 & 0.3241 & \\
\hline
\end{tabular}

Notes: See notes to Table 6. 
Table 8: Correlation matrix of satisfaction indicators

\begin{tabular}{|l|c|c|c|c|c|c|c|}
\hline & Achievement & Initiative & Influence & Training & Pay & $\begin{array}{c}\text { Job } \\
\text { security }\end{array}$ & $\begin{array}{c}\text { Work } \\
\text { itself }\end{array}$ \\
\hline Achievement & 1.000 & & & & & & \\
\hline Initiative & 0.639 & 1.000 & & & & & \\
\hline Influence & 0.592 & 0.727 & 1.000 & & & & \\
\hline Training & 0.383 & 0.383 & 0.420 & 1.000 & & & \\
\hline Pay received & 0.272 & 0.274 & 0.315 & 0.334 & 1.000 & & \\
\hline Job security & 0.331 & 0.316 & 0.356 & 0.357 & 0.306 & 1.000 & \\
\hline Work itself & 0.681 & 0.547 & 0.537 & 0.371 & 0.284 & 0.352 & 1.000 \\
\hline
\end{tabular}

Table 9: Weights used in composite satisfaction index

\begin{tabular}{|l|c|}
\hline Satisfaction indicator & Scaled weight \\
\hline Sense of achievement from work & 0.151 \\
\hline Scope for using own initiative & 0.151 \\
\hline Amount of influence over job & 0.157 \\
\hline Training received & 0.150 \\
\hline Amount of pay received & 0.131 \\
\hline Job security & 0.123 \\
\hline Work itself & 0.139 \\
\hline
\end{tabular}


Table 10: Training and composite mean satisfaction level as determinants of workplace performance - deviations from industry means

\begin{tabular}{|c|c|c|c|c|c|c|}
\hline \multirow{3}{*}{$\begin{array}{l}\text { Average highest } \\
\text { qualification }\end{array}$} & \multicolumn{3}{|c|}{ Quit rate } & \multicolumn{3}{|c|}{ Absence rate } \\
\hline & $0.012^{*}$ & $0.013^{*}$ & 0.011 & 0.205 & 0.112 & 0.072 \\
\hline & $(0.007)$ & $(0.007)$ & $(0.007)$ & $(0.248)$ & $(0.243)$ & $(0.259)$ \\
\hline \multirow{2}{*}{$\%$ Overskilled } & $0.104 * * *$ & $0.102 * *$ & $0.105 * *$ & -0.915 & -0.665 & -0.651 \\
\hline & $(0.040)$ & $(0.040)$ & $(0.041)$ & $(1.315)$ & $(1.274)$ & $(1.307)$ \\
\hline \multirow[t]{2}{*}{ \% Underskilled } & 0.118 & 0.153 & 0.117 & -3.728 & -3.335 & -3.232 \\
\hline & $(0.104)$ & $(0.106)$ & $(0.103)$ & $(2.937)$ & $(3.089)$ & $(2.838)$ \\
\hline \multirow{3}{*}{$\begin{array}{l}\text { Satisfaction } \\
\text { indicator }\end{array}$} & & & & & & \\
\hline & -0.013 & -0.011 & -0.004 & $-3.737 * * *$ & $-3.551 * * *$ & $-3.692 * * *$ \\
\hline & $(0.020)$ & $(0.021)$ & $(0.021)$ & $(1.001)$ & $(0.993)$ & $(0.942)$ \\
\hline \multicolumn{7}{|l|}{ Training measure } \\
\hline \multicolumn{7}{|c|}{ Proportion of LOG trained } \\
\hline \multirow[t]{2}{*}{$1-19 \%$} & $-0.070 * *$ & & & -1.550 & & \\
\hline & $(0.028)$ & & & $(1.052)$ & & \\
\hline \multirow[t]{2}{*}{$20-39 \%$} & -0.029 & & & -1.233 & & \\
\hline & $(0.036)$ & & & $(1.178)$ & & \\
\hline \multirow[t]{2}{*}{$40-59 \%$} & -0.021 & & & $-2.473 * *$ & & \\
\hline & $(0.031)$ & & & $(1.090)$ & & \\
\hline \multirow[t]{2}{*}{$60-79 \%$} & $-0.053^{*}$ & & & -1.551 & & \\
\hline & $(0.032)$ & & & $(1.238)$ & & \\
\hline \multirow[t]{2}{*}{$70-99 \%$} & $-0.069^{*}$ & & & $-3.124 * *$ & & \\
\hline & $(0.036)$ & & & $(1.250)$ & & \\
\hline \multirow[t]{2}{*}{$100 \%$} & $-0.058 * *$ & & & -0.179 & & \\
\hline & $(0.026)$ & & & $(1.226)$ & & \\
\hline \multicolumn{7}{|c|}{ Time LOG spend training (days) } \\
\hline \multirow[t]{2}{*}{$<1$} & & -0.027 & & & -0.225 & \\
\hline & & $(0.045)$ & & & $(1.591)$ & \\
\hline \multirow[t]{2}{*}{1 to $<2$} & & $-0.071 * *$ & & & $-1.853^{*}$ & \\
\hline & & $(0.028)$ & & & $(1.013)$ & \\
\hline \multirow[t]{2}{*}{2 to $<5$} & & $-0.071 * * *$ & & & -1.088 & \\
\hline & & $(0.024)$ & & & $(1.002)$ & \\
\hline \multirow[t]{2}{*}{5 to $<10$} & & $-0.070 * * *$ & & & -0.300 & \\
\hline & & $(0.027)$ & & & $(1.321)$ & \\
\hline \multirow[t]{2}{*}{$\geq 10$} & & $-0.049 *$ & & & -0.384 & \\
\hline & & $(0.027)$ & & & $(1.388)$ & \\
\hline \multirow{2}{*}{$\begin{array}{l}\text { Proportion of } \\
\text { employees trained }\end{array}$} & & & -0.017 & & & 0.522 \\
\hline & & & $(0.036)$ & & & (1.409) \\
\hline R-squared & 0.157 & 0.159 & 0.138 & 0.078 & 0.069 & 0.069 \\
\hline $\begin{array}{l}\text { Wald Test } \\
\mathrm{H}_{0}: \text { All } \\
\text { coefficients on } \\
\text { training variables } \\
=0\end{array}$ & 1.58 & 2.14 & & 2.34 & 1.22 & \\
\hline P-value & 0.1486 & 0.0586 & & 0.0300 & 0.2966 & \\
\hline
\end{tabular}

Notes: See notes to Table 6. 
Table 11: Training and mean composite satisfaction level as determinants of workplace performance-deviations from industry means

\begin{tabular}{|c|c|c|c|c|c|c|c|c|c|}
\hline & \multicolumn{3}{|c|}{ Financial performance } & \multicolumn{3}{|c|}{ Labour productivity } & \multicolumn{3}{|c|}{ Quality } \\
\hline \multirow{2}{*}{$\begin{array}{l}\text { Average highest } \\
\text { qualification }\end{array}$} & $0.155^{*}$ & $0.146 *$ & $0.155^{*}$ & $0.064 * *$ & $0.061^{*}$ & $0.059 *$ & $0.069 * * *$ & $0.066 * * *$ & $0.062 * *$ \\
\hline & $(0.079)$ & $(0.081)$ & $(0.082)$ & $(0.032)$ & $(0.031)$ & $(0.033)$ & $(0.025)$ & $(0.025)$ & $(0.026)$ \\
\hline \multirow[t]{2}{*}{ \% Overskilled } & 0.300 & 0.284 & 0.288 & 0.191 & 0.171 & 0.188 & 0.051 & 0.053 & 0.071 \\
\hline & $(0.186)$ & $(0.189)$ & $(0.188)$ & $(0.173)$ & $(0.173)$ & $(0.179)$ & $(0.159)$ & $(0.163)$ & $(0.162)$ \\
\hline \multirow[t]{2}{*}{ \% Underskilled } & $0.853 *$ & $0.915^{*}$ & $0.869 *$ & 0.362 & 0.573 & 0.379 & -0.055 & 0.167 & -0.021 \\
\hline & $(0.463)$ & $(0.508)$ & $(0.461)$ & $(0.486)$ & $(0.514)$ & $(0.498)$ & $(0.392)$ & $(0.404)$ & $(0.400)$ \\
\hline \multirow{2}{*}{$\begin{array}{l}\text { Satisfaction } \\
\text { indicator }\end{array}$} & $0.287 * *$ & $0.270 * *$ & $0.245^{* *}$ & $0.427 * * *$ & $0.413^{* * *}$ & $0.395 * * *$ & $0.296 * * *$ & $0.295 * * *$ & $0.308 * * *$ \\
\hline & $(0.112)$ & $(0.111)$ & $(0.107)$ & $(0.109)$ & $(0.112)$ & $(0.112)$ & $(0.087)$ & $(0.092)$ & $(0.090)$ \\
\hline \multicolumn{10}{|l|}{ Training measure } \\
\hline \multicolumn{10}{|c|}{ Proportion of LOG trained } \\
\hline \multirow[t]{2}{*}{$1-19 \%$} & $0.193 *$ & & & 0.199 & & & -0.058 & & \\
\hline & $(0.115)$ & & & $(0.123)$ & & & $(0.097)$ & & \\
\hline \multirow[t]{2}{*}{$20-39 \%$} & 0.150 & & & 0.005 & & & -0.098 & & \\
\hline & $(0.138)$ & & & $(0.140)$ & & & $(0.103)$ & & \\
\hline \multirow[t]{2}{*}{$40-59 \%$} & 0.083 & & & -0.023 & & & $-0.370 * * *$ & & \\
\hline & $(0.167)$ & & & $(0.153)$ & & & $(0.119)$ & & \\
\hline \multirow[t]{2}{*}{$60-79 \%$} & $0.300 * *$ & & & 0.194 & & & -0.051 & & \\
\hline & $(0.153)$ & & & $(0.159)$ & & & $(0.143)$ & & \\
\hline \multirow[t]{2}{*}{$70-99 \%$} & 0.140 & & & 0.043 & & & $-0.330 * *$ & & \\
\hline & $(0.177)$ & & & $(0.199)$ & & & $(0.136)$ & & \\
\hline \multirow[t]{2}{*}{$100 \%$} & $0.279 * *$ & & & $0.264^{* *}$ & & & 0.010 & & \\
\hline & $(0.115)$ & & & $(0.128)$ & & & $(0.100)$ & & \\
\hline \multicolumn{10}{|c|}{ Time LOG spend training (days) } \\
\hline \multirow[t]{2}{*}{$<1$} & & 0.223 & & & 0.203 & & & 0.087 & \\
\hline & & $(0.251)$ & & & $(0.148)$ & & & $(0.127)$ & \\
\hline \multirow[t]{2}{*}{1 to $<2$} & & 0.001 & & & -0.004 & & & $-0.205 * *$ & \\
\hline & & $(0.112)$ & & & $(0.129)$ & & & $(0.096)$ & \\
\hline \multirow[t]{2}{*}{2 to $<5$} & & $0.249 * *$ & & & $0.208^{*}$ & & & -0.058 & \\
\hline & & $(0.109)$ & & & $(0.118)$ & & & $(0.095)$ & \\
\hline \multirow[t]{2}{*}{5 to $<10$} & & 0.124 & & & 0.122 & & & -0.084 & \\
\hline & & $(0.131)$ & & & $(0.135)$ & & & $(0.107)$ & \\
\hline
\end{tabular}




\begin{tabular}{|c|c|c|c|c|c|c|c|c|c|}
\hline$\geq 10$ & & $0.366^{* * *}$ & & & $0.385^{* * *}$ & & & 0.030 & \\
\hline $\begin{array}{l}\text { Proportion of } \\
\text { employees trained }\end{array}$ & & & $(0.153)$ & & & $(0.160)$ & & & $(0.131)$ \\
\hline R-squared & 0.110 & 0.119 & 0.100 & 0.103 & 0.108 & 0.083 & 0.118 & 0.095 & 0.084 \\
\hline
\end{tabular}




\section{References}

Akerlof, G. (1982), Labor contracts as a partial gift exchange, Quarterly Journal of Economics, 97: 543-569.

Akerlof, G. and Yellen, J. (1986), Efficiency Wage Models of the Labor Market, Cambridge University Press: Cambridge.

Akerlof, G., Rose, A. and Yellen, J. (1988), Job switching and job satisfaction in the US Labor Market, Brookings Papers on Economic Activity, 2: 495-582.

Allen J. and van der Velden R. (2001), Education mismatches versus skill mismatches: effects on wage, job satisfaction and on-the-job search, Oxford Economic Papers, 53: 434452.

Barmby T. (2002), Worker absenteeism; a discrete hazard model with bivariate heterogeneity, Labour Economics, 9: 469-476.

Barmby, T.A., Orme, C.D. and Treble, J.G. (1991), Worker absenteeism: An analysis using microdata, Economic Journal 101: 214-229.

Barmby, T., Orme, C. and Treble, J. (1995), Worker absence histories: a panel data study, Labour Economics, 2: 53-65.

Barmby, T., Sessions, J. and Treble, J.G. (1994), Absenteeism, efficiency wages and shirking, Scandinavian Journal of Economics, 94: 561-566.

Barmby, T. and Stephan G. (2000), Worker absenteeism: why firm size may matter, The Manchester School, 68: 568-577.

Barrett, A. and O’Connell, P.J. (1998), Does training generally work? The returns to incompany training, Centre for Economic Policy Research Paper No. 1879, London.

Bartel A.P. (1994), Productivity gains from the implementation of employee training programs, Industrial Relations, 33: 411-425.

Bartel, A.P. and Lichtenberg, F.R. (1987), The comparative advantage of educated workers in implementing new technology, The Review of Economics and Statistics, 69: 1-11.

Battu, H., Belfield, C.R. and Sloane, P.J. (1999), Overeducation among graduates: a cohort view, Education Economics, 17: 21-38.

Battu, H., Belfield, C.R. and Sloane, P.J. (2000), How well can we measure graduate overeducation and its effects? National Institute Economic Review, 171: 82-93.

Bauer, T.K. (2004), High performance workplace practices and job satisfaction: evidence from Europe, IZA Discussion Paper No. 1265, Bonn.

Becker, B.E. and Huselid, M.A. (1998), Human resources strategies, complementarities and firm performance, SUNY Buffalo, unpublished manuscript. 
Bertrand, M. and Mullainathan, S. (2001), Do people mean what they say? Implications for subjective survey data, American Economic Review, 91: 67-72.

Borjas, G. (1979), Job satisfaction, wages and unions, Journal of Human Resources 14: 2140.

Bridges, S. and Mumford, K. (2001), Absenteeism in the UK: a comparison across genders, The Manchester School, 69: 276-284.

Brown, D. and McIntosh, S. (1998), If you're happy and you know it...Job satisfaction in the low wage service sector, Centre for Economic Performance Discussion Paper 0405, London.

Buchel, B. (2002), The effects of overeducation on productivity in Germany - the firm's viewpoint, Economics of Education Review, 21: 263-275.

Burdett, K. and Mortensen, D.T. (1998), Wage differentials, employer size, and unemployment, International Economic Review, 39: 257-273.

Chaplin, J., Mangla, J., Purdon, S. and Airey, C. (2005), The Workplace Employment Relations Survey (WERS) 2004 Technical Report (Cross-Section and Panel Surveys), prepared for Department of Trade and Industry.

Clark, A., Georgellis, Y and Sanfey, P. (1998), Job satisfaction, wage changes and quits: evidence from Germany, Research in Labor Economics, 17: 95-121.

Clark, A.E. and Oswald, A. (1996), Satisfaction and comparison income, Journal of Public Economics, 61: 359-381.

Clegg, C.W. (1983), Psychology of employee lateness, absence and turnover: a methodological critique and an empirical study, Journal of Applied Psychology, 68: 88-101.

Cosh, A., Duncan J. and Hughes, A. (1998) Investment in training and small firm growth and survival: an empirical analysis for the UK 1987-1996, DfEE Research Brief No. 36, London.

Cosh, A., Hughes, A. and Weeks, A. (2000), The relationship between training and employment in SMEs, DfEE Research Report No. 7, London.

Cosh, A., Hughes, A., Bullock, A. and Potton, M. (2003), The relationship between training and business performance, DfEE Research Report No. 245, London.

Dearden,L., Reed H. and Van Reenan, J. (2000), Who gains when workers train? Training and corporate productivity in a panel of British industries, IFS Working Paper 00/04, London.

Dearden, L., Reed, H. and Van Reenan, J. (2006), The impact of training on productivity and wages: evidence from British panel data, Oxford Bulletin of Economics and Statistics, 68: 397-421.

Drago, R. and Wooden, M. (1992), The determinants of labor absence: economic factors and workgroup norms across countries, Industrial and Labor Relations Review; 45: 764-778. 
Faragher, E.B., Cass, M. and Cooper, C.L. (2005), The relationship between job satisfaction and health: a meta-analysis, Occupational and Environmental Medicine; 62: 105-112.

Farell, D. (1983), Exit, voice, loyalty and neglect as responses to job satisfaction, a multidimensional scaling study, Academy of Management Journal, 26: 596-607.

Freeman, R.B. (1978), Job satisfaction as an economic variable. American Economic Review: Papers and Proceedings, 68, 135-141.

Freeman, R.B. and Medoff, J.L. (1984), What Do Unions Do? Basic Books: New York.

Frijters, P., Shields, M.A. and Wheatley-Price, S. (2004), To teach or not to teach? Panel data evidence on the quitting decision, IZA Discussion Paper No.1164, Bonn.

Green, F. and Tsitianis, N. (2005), An investigation of national trends in job satisfaction in Britain and Germany, British Journal of Industrial Relations, 43: 401-429.

Grugulis I. and Stoyanova D. (2006), Skills and performance, SKOPE Issues Paper No. 9.

Hamermesh, D.S. (1977), Economic aspects of job satisfaction, in Ashenfelter, O.C. and Oates, W.E. (Eds.), Essays in Labor Market Analysis, Wiley, New York, 53-72.

Hersch, J. (1991), Education match and job match, Review of Economics and Statistics, 73 : 140-144.

Hersch, J. (1995), Optimal ‘mismatch’ and promotions, Economic Inquiry, 33: 611-624.

Ichino, A. and Riphahn, R.T. (2005), The effect of employment protection on worker effort: a comparison of worker absenteeism during and after probation, Journal of European Economic Association, 3: 120-143.

Jovanovic, B. (1979), Job matching and the theory of turnover, Journal of Political Economy, 87: $972-990$.

Kristensen, N. and Westergård-Nielsen, N. (2004), Does low job satisfaction lead to job mobility?, IZA Discussion Paper No. 1026, Bonn.

Labour Market Trends (2003), Sickness absence, Labour Market Trends, 111: 65.

Locke, E.A. (1976), The nature and causes of job satisfaction, in Dunnette, M.D. (Ed.) Handbook of Industrial and Organizational Psychology, Rand McNally College Publishing Company, Chicago.

Machin, S. and Stewart, M. (1996), Trade unions and financial performance, Oxford Economic Papers, 48: 213-241.

Machin, S.J. (1991), The productivity effects of unionization and firm-size in British engineering firms, Economica, 58(232): 479-490. 
Mason, G., van Ark, B. and Wagner, K. (1996), Workforce Skills, Product Quality and Economic Performance, Acquiring Skills: Market Failures, their Symptoms and Policy Responses, Cambridge University Press, Cambridge.

Oi, W. (1962), Labor as a quasi-fixed factor. Journal of Political Economy, 70(6): 538-55.

Paringer, L. (1983), Women and absenteeism: health or economics, American Economic Review, 73: 123-127.

Petty, M., McGee G.W. and Cavender, J.W. (1984), A meta-analysis of the relationships between individual job satisfaction and individual performance, The Academy of Management Review, 9: 712-721.

Shields, M.A. and Ward, M. (2001), Improving nurse education in the National Health Service in England: the impact of job satisfaction on intentions to quit, Journal of Health Economics, 20: 677-701.

Siebern-Thomas, F. (2005) Job quality in European labour markets, in Bazen S., Lucifora C. and Salverda W. (Eds.), Job Quality and Employer Behaviour, Palgrave Macmillan, Basingstoke, Hants, 31-66.

Sloane, P., Jones, R. and Leontardi, R. (2005), Are low paid jobs of low quality? Some British evidence, International Journal of Economic Research, 2: 147-172.

Steers, R.M. and Rhodes, S.R. (1978), Major influences on employee attendance: a process model, Journal of Applied Psychology, 63: 391-407.

Tamkin, P., Giles, L., Campbell, M. and Hillage, J. (2004), Skills Pay: The Contribution of Skills to Business Success, Skills for Business Research Report No. 5.

Tsang, M.C. and Levin, H.M. (1985), The economics of overeducation, Economics of Education Review, 4: 93-104.

Tsang, M.C. (1987), The impact of underutilization of education on productivity: a case study of the US Bell companies, Economics of Education Review, 6: 239-254.

Tsang, M.C., Rumberger, R.W. and Levin, H.M. (1991), The impact of surplus schooling on work productivity, Industrial Relations, 30: 209-28.

Verhaest, D. and Omey, E. (2004), The impact of overeducation and its measurement, FEB Working Paper No. 2004/215.

Vroom, V.H. (1964), Work and Motivation, New York: Wiley.

Wegge, J., Schmidt, K-H., van Dick, R. and Parkes, C. (2004), Taking a sickie: job satisfaction and job involvement as interactive predictors of absenteeism, Aston Business School Research Paper RP 0427.

Zwick T. (2006), The impact of training intensity on establishment productivity, Industrial Relations, 45(1): 26-46. 